GSI Journals Serie A: Advancements in Tourism, Recreation and Sports Sciences

(GSI Dergileri Seri A: Turizm, Rekreasyon ve Spor Bilimlerindeki Gelişmeler)

ATRSS 2021, 4 (2): 135-146 - Research Article/Araştırma Makalesi - Received/Geliş T.: 08.06.2021 - Published/Kabul T.: 05.07.2021

\title{
Türk Turizminde Yükselen Destinasyonların Konumlandırma Stratejilerinin Belirlenmesi
}

Serkan TÜRKMEN, Çanakkale Onsekiz Mart Üniversitesi, Turizm Fakültesi, Seyahat İşletmeciliği ve Turist Rehberliği Anabilim Dalı, serkanturkmen17@hotmail.com, Çanakkale, Türkiye, ORCID: 0000-0003-2556-9757

Mehmet Oğuzhan İLBAN, Balıkesir Üniversitesi, Burhaniye Uygulamalı Bilimler Yüksekokulu, Gastronomi ve Mutfak Sanatları Bölümü, ilban@balikesir.edu.tr, Balıkesir, Türkiye, ORCID: 0000-0002-7557-9817

Merve KARAKAŞ, Balıkesir Üniversitesi, Sosyal Bilimler Enstitüsü, Konaklama İşletmeciliği Anabilim Dalı, mervekarakass10@gmail.com, Balıkesir, Türkiye, ORCID: 0000-0002-0014-1781

Öz

Bu çalışmanın amacl; Türk turizminde popülerliği gitgide artan turistik destinasyonların konumlandırma stratejilerini belirlemektir. Özellikle sosyal medyanın gücüyle yeni çekim yerlerine yönelik turist tercihleri hızla artabilmektedir. Sosyal medya aracılı̆̆ı ile Türkiye'de en çok ön plana çıkan destinasyonlardan Çıldır Gölü, Salda Gölü, Seferihisar, Isparta-Kuyucak Köyü, Göbeklitepe, Bozcaada ve Ormanya-Hobbit Köyü'ne ait kurumsal web sayfalar içerik analizi yöntemi ile incelenmiştir. Destinasyonların web sayfaları üzerinden turistlere iletmeye çalı̧̧ıkları mesajlar alt temalara ayrılmış ve bu temalar Kotler'in (2011) konumlandırma stratejileri kapsamında değerlendirilmiştir. Araştırma sonucunda, ele alınan destinasyonların konumlandırılmasında kullanılan altı farklı konumlandırma stratejisi belirlenmiştir. Bu stratejiler; Rakip Konumlandırması, Kullanıcı Konumlandırması, Kategori Konumlandırması, Kullanım/Uygulama Konumlandırması, Özellik Konumlandırması, Yarar Konumlandırmasıdır.

Anahtar Kelimeler: Konumlandırma, Destinasyon Konumlandırma, Türkiye'deki Yeni Trend Destinasyonlar

\section{Determination of Positioning Strategies of the Rising Destinations in Turkish Tourism}

\begin{abstract}
The aim of this study is to determine the positioning strategies of new trend touristic destinations in Turkey. Especially with the power of social media, there can be a rapid increase in tourist demand for new attraction places. The corporate web pages of Çıldir Lake, Salda Lake, Seferihisar, Isparta-Kuyucak Village, Göbeklitepe, Bozcaada and Ormanya-Hobbit Village, which are the most prominent destinations in Turkey through social media, were analyzed by content analysis method. Sub-themes were created from the messages that destinations try to convey to tourists on their web pages and sub-these themes were evaluated within the scope of Kotler's (2011) positioning strategies. As a result of the research, six different positioning strategies used in positioning of new trend destinations were determined. These strategies are; Competitor Positioning, User Positioning, Category Positioning, Usage/Application Positioning, Attribute Positioning, Benefit Positioning.
\end{abstract}

Keywords: Positioning, Destination Positioning, New Trend Destinations in Turkey 


\section{Giriş}

Turist tercihlerindeki değişimler ve yeni turizm yatırımları ile birlikte kıyı turizmi dışında alternatif turizme yönelik talepler artmaktadır. (Alili, 2017:1). Deniz, kum ve güneş dışında tarih, kültür, sanat, gastronomi, müzik, sağlık ve spor gibi farklı turizm çeşitleri ön plana çıkmaktadır. Alternatif turizm merkezlerinin ortaya çıkması ile birlikte turistler farklı deneyimler aramakta ve bu deneyimleri elde edebileceği turizm destinasyonlarına yönelmektedir. Özellikle kitle turizminden farklı olarak turist-yerel halk arasında etkileşimin daha yüksek olabileceği özgün destinasyonlar ön plana çıkmaktadır (Kaba ve Emekli, 2018: 112).

Uluslararası toplumlarda sosyal yapıların değişmesi ile birlikte yaşam tarzlarında da birtakım değişiklikler olmuştur ve bu duruma bağlı olarak bireysel seyahat eden turist sayıları artmaya başlamıştır (Jordan ve Gibson, 2005). Doğal olarak insanlar kendilerini daha özgür hissettiği ve bireysel ilgilerini ve ihtiyaçlarını karşılayan destinasyonlara bireysel olarak seyahat etme arzusu içerisindedirler (Osman vd., 2020).

Değişen turist tercihleri ile birlikte turizm, özellikle kırsal bölgelerde yerel kültürün değerlenmesine katkı sağlayarak bu alanların sosyal ve ekonomik anlamda gelişmesine fırsat sunmaktadır. Bunun farkına varan destinasyon ve bölgeler yeni turizm yatırımları yapmakta ve turizm pazarından en yüksek değeri elde edebilmek için birbirleri ile rekabet içerisine girmektedirler (Chernikova vd., 2015). Dolayısıyla turizm pazarında alternatif ve farklı deneyim sunan bu destinasyonların sayısı artmakta ve yoğun rekabet ortamı içerisinde olan bu destinasyonlar turistleri ikna edebilmek için yoğun iletişim çabalarına girmektedirler (Akpulat, 2017; 444). Yoğun rekabet ortamı içerisindeki bu destinasyonların diğer destinasyonlardan farklarını ortaya koyabilmeleri gerekmektedir. Destinasyonların tüketici tercihlerini arzu ettikleri şekilde yönlendirebilmeleri ve tercih edilir destinasyonlar haline gelebilmeleri için kendilerini turist zihninde doğru bir şekilde "konumlandırmaları" çok önemlidir (Şıker ve Akın, 2012; Castañeda-García vd., 2020).

Destinasyonları pazarda ön plana çıkarmanın en etkili yolu rakiplerinden farklılaştırmaktır. Turistlerin gidebileceği çok sayıda destinasyon içerisinde farklı bir destinasyon markası yaratarak tercih edilirliğin arttırılması gerekmektedir (Türkmen vd., 2018). Bunun için de destinasyonun doğru konumlandırılması büyük önem arz etmektedir. Literatürde destinasyon konumlandırma ile ilgili yapılmış çeşitli araştırmalar bulunmaktadır. Bu araştırmalarda belirli bir destinasyonun veya destinasyonların konumlandırma açısından değerlendirilmesi üzerinde durulmaktadır (Akpulat, 2017; Karabıyık ve Sümer İnci, 2012; Evren, 2016). Ancak günümüzde turistlerce tercih edilirliği artan destinasyonların hangi konumlandırma stratejilerini kullanarak rakiplerinden farklılaştığı konusunda çok kısıtlı çalışma vardır. Destinasyonların konumlandırılmasında hangi stratejilerin kullanıldığına vurgu yapmak farklılaşmanın belirlenmesi açısından oldukça önemlidir. Destinasyonların konumlandırma stratejileri arasındaki farklılıkların belirlenmesi bu destinasyonların öne çıkardıkları yönlerinin karşılaştırılması açısından da önemlidir (Çatı, Kethüda ve Bilgin, 2016: 220). Bu doğrultuda araştırmanın temel konusu Türkiye' de son zamanlarda turist ziyaretini hızlı bir şekilde artıran destinasyonların hangi stratejilere göre ve hangi özellikler çerçevesinde konumlandırıldığının tespit edilmesidir. Buradan hareketle çalışmanın amac1; Türk turizminde popülerliği gitgide artan turistik bazı destinasyonların konumlandırma stratejilerinin belirlenmesidir. Bu kapsamda, günümüz trendlerinin çok hızlı bir şekilde yayılmasını sağlayan sosyal medya platformalarından yararlanılmış ve Türkiye'nin son zamanlarda ön plana çıkan (trend) destinasyonlarının; Çıldır Gölü, Salda Gölü, Seferihisar, Isparta-Kuyucak Köyü, Göbeklitepe, Bozcaada ve Ormanya-Hobbit Köyü olduğu belirlenmiştir.

\section{Marka Konumlandirma}

Marka konumlandırma kavramı ilk olarak 1972 yılında Al Ries ve Jack Trout aracılığı ile bir çalışmada gündeme gelmiştir (Kalafatis vd, 2000). Literatürde konumlandırma ile ilgili birçok tanım yapılmıştır. En genel anlamda konumlandırma bir ürünü/markayı tüketicinin zihninde bir yere yerleştirme çabası olarak tanımlanmaktadır (İnce ve Uygurtürk, 2019: 228). Konumlandırma, ürüne ya da hizmete değil tüketicinin 
zihnine yapılan bir işlemdir. Aynı zamanda konumlandırma ürün ya da hizmetlerin rakiplerinden farklılaştırılmasıdır (Çiftçi ve Cop, 2007).

Konumlandırma sürecinde markanın devamlılı̆̆ının sağlanabilmesi için doğru yapılmış bir konumlandırma son derece önemlidir. Şıker ve Akın (2012) ilk olma, tek olma ve duygulara hitap edebilme noktalarında doğru konumlandırmanın önemine vurgu yapmıştır. İşletme veya markalar için tüketici zihninde ürün veya süreçler ile ilgili bir konumu ilk ortaya atan ve sürdüren olunmalıdır. Tek olma konusu ise işletmeleri rakiplerinden farklı olarak belirli bir özelliği taşıması ve kimseye benzememesidir. Tüketici duygularına hitap edilmesi ve tüketicinin bu duyguyu taşıması, işletmeyi yer edici bir şekilde konumlandıracağı anlamına gelir. Bu üç durumun marka konumlandırmasında dikkat edilmesi gereken unsurlar olduğu söylenebilir. Doğal olarak tüketici zihninde farklı ve yararlı şekilde konumlanmış işletme veya markalar rakiplerine göre avantajlı pozisyona geçmiş olurlar (Cengiz, 2006).

Konumlandırmada dikkat edilmesi gereken bir başka husus da konumlandırma stratejileridir. Konumlandırma stratejileri, markanın tanınmasını sağlamanın yanında markayı devamlı rakiplerine göre avantajlı pozisyona geçirecek farklılaştırma çaba ve süreçlerini içerir (Fuchs ve Diamanropoulos, 2010). Konumlandırma stratejileri tüketicilerin markayı algılama şeklini belirlemektedir. Burada önemli olan işletmelerin birçok marka konumlandırma stratejisi arasında en etkili olabilecekleri doğru zaman ve yerde kullanarak konumlarını koruma ve geliştirmenin yollarını aramalarıdır (Aydınol, 2010: 50). Marka konumlandırmada kullanılan birçok strateji vardır. Burada önemli olan işletmelerin kendilerine en uygun stratejiyi seçip, doğru yöntemlerle uygulamasıdır. Çakır (2017), Aaker ve Shansby (1982) ve Kotler (2001) tarafından ifade edilen konumlandırma stratejilerini derlemiş ve dokuz adet konumlandırma stratejisi olduğunu ifade etmiştir. İnce ve Uygurtürk'ün (2019: 229) tablolaştırdığı bu konumlandırma stratejileri Tablo 1'de gösterilmiştir.

Tablo 1. Marka Konumlandırma Stratejileri

\begin{tabular}{|l|l|}
\hline \multicolumn{1}{|c|}{ STRATEJI } & \multicolumn{1}{|c|}{ AÇıKLAMA } \\
\hline $\begin{array}{l}\text { 1. Ürün Özelliğini Vurgulayan } \\
\text { Konumlandırma }\end{array}$ & $\begin{array}{l}\text { Mal ve hizmetlerin hem kendine has hem de rakiplerine özgü özelliklerini } \\
\text { ön plana çıarmak. }\end{array}$ \\
\hline $\begin{array}{l}\text { 2. Fiyat-Kalite İlişkisine Göre } \\
\text { Konumlandırma }\end{array}$ & Mal veya hizmetin fiyat veya kalite boyutunu öz plana çıkarmak. \\
\hline $\begin{array}{l}\text { 3. Ürünün Kullanımını Vurgulayan } \\
\text { Konumlandırma }\end{array}$ & $\begin{array}{l}\text { Mal veya hizmetin nerede, ne zaman, nasıl ve ne şekilde kullanılmasını } \\
\text { vurgulamak. }\end{array}$ \\
\hline $\begin{array}{l}\text { 4. Ürün Sınıfını Vurgulayan } \\
\text { Konumlandırma }\end{array}$ & $\begin{array}{l}\text { Mal veya hizmetin aynı ürün kategorisindeki ürünlerden farklı olan } \\
\text { yönünü vurgulamak. }\end{array}$ \\
\hline $\begin{array}{l}\text { 5. Ürünü Kullananları Vurgulayan } \\
\text { Konumlandırma }\end{array}$ & $\begin{array}{l}\text { Mal veya hizmeti kullanacak hedef kitlenin kimlik ve özelliklerinin net } \\
\text { olarak vurgulanması. }\end{array}$ \\
\hline $\begin{array}{l}\text { 6. Rakipler ile Kıyaslayıcı } \\
\text { Konumlandırma }\end{array}$ & $\begin{array}{l}\text { Mal ve hizmetin rakiplerin mal veya hizmetlerine göre sahip olduğu farklı } \\
\text { özellikleri vurgulamak. }\end{array}$ \\
\hline $\begin{array}{l}\text { 7. Kültürel Semboller ile } \\
\text { Konumlandırma }\end{array}$ & $\begin{array}{l}\text { Mal veya hizmeti kullanıcıları tarafından kabul görmüş örf, adet, gelenek } \\
\text { ve kültürel semboller ile vurgulamak. }\end{array}$ \\
\hline $\begin{array}{l}\text { 8. Yaşam Biçimine Odaklı } \\
\text { Konumlandırma }\end{array}$ & $\begin{array}{l}\text { Toplumsal katmanının tüketim alıskanlıklarını göz önüne alarak } \\
\text { vurgulamak. }\end{array}$ \\
\hline $\begin{array}{l}\text { 9. Marka Kişiliğine Odaklı } \\
\text { Konumlandırma }\end{array}$ & $\begin{array}{l}\text { Mal veya hizmetlere insan kiş̧iliklerinin özellikleri yüklenerek } \\
\text { vurgulamak. }\end{array}$ \\
\hline
\end{tabular}

\subsection{Destinasyon Konumlandırma}

Destinasyon, mal ve hizmet bileşenlerinin turistin tüketimine sunulduğu yerdir. Bu yerlerin pazarlamasında dikkat edilmesi gereken en önemli unsurlar içerisinde imaj ve konumlandırma 
kavramları yer alır. $\mathrm{Bu}$ açıdan destinasyon markalamasının en önemli silahlarından biri konumlandırmadır (Atsız ve Kızılırmak, 2017: 28-29). Pazarlama ve marka faaliyetlerinin her aşaması önemlidir. Ancak özellikle mevcut durumu doğru şekilde yansıtacak çekici bir imajın oluşturulması ve bunun gücüyle turist zihninde istenilen bir konumun elde edilmesi destinasyonların markalaşma sürecini hızlandıracak ya da marka gücünü arttıracaktır (Ersun ve Arslan, 2011: 237).

Dünyada tercih edilen popüler birçok destinasyon belirli bir pazarlama planı dahilinde ya da ziyaret eden turistlerin kendi çabalarıyla konumlandırılmışlardır. Bunlar arasında en çok bilinenlerden İtalya'nın moda ile akla gelmesi ya da Paris'in romantizm ve aşk ile konumlanması örnek olarak verilebilir (Kuvvetli, 2014). Bu bağlamda destinasyon konumlandırması; pazar bölümlendirme sonrasında hedeflenen pazar içindeki turistlerin destinasyonu istenilen şekilde algılamasını sağlama çabasıdır. Mevcut ve potansiyel ziyaretçiler iletişim kanallarının artması ile birlikte destinasyonlarda elde ettikleri deneyimleri duyurmakta ve bu sayede hem deneyim hem de duyumlar sayesinde destinasyonların imajı oluşmaktadır. Ancak bu imajın kalıcı ve istenilen bir şekilde konumlanması için destinasyon yöneticilerinin ve pazarlamacılarının hizmet kalitesi yanında iletişim kanallarını doğru kullanmaları gerekmektedir (Saqib, 2019). Bu doğrultuda, iyi bir destinasyon konumlandırması için iki konuya vurgu yapılmaktadır. Bunlar "farklılaşma" ve "destinasyon özelliklerinin önemi-dikkat çekiciliği-belirleyiciliği" kavramlarıdır. Farklılaşma, konumlandırmanın temellerini oluşturmaktadır. Destinasyonlar için de aynılaşan sıradan destinasyon grubu içinden kurtulmanın en temel yolu olumlu yönde farklılaşmaktadır. Bu durumun başarılması destinasyon yöneticilerinin en temel görevi ve zorluğu olarak değerlendirilebilir. Çünkü küreselleşme ve uluslararası seyahatlerde yaşanan kolaylıklar sayesinde turistlerin karşısında benzer ürünleri sunan çok sayıda destinasyon bulunmaktadır (Hultman vd., 2015). Bu bağlamda, destinasyonları rakiplerinden farklılaştıran etkili konumlandırma stratejilerinin öneminin de arttığı söylenebilir.

Konumlandırma açısından önemli görünen ikinci konu, destinasyon özelliklerinin önemi, dikkat çekiciliği ve belirleyiciliğidir. Destinasyonun sahip olduğu özellikler turist motivasyonlarını karşılamalıdır. Turistlerin ihtiyaçlarını karşılayabilecek destinasyon özelliklerinin turist zihnine doğru bir şekilde konumlanmasının sağlanması destinasyonlara rekabet avantajı sağlayacaktır (Pike, 2008).

\subsection{Destinasyon Konumlandırma Stratejisi}

Destinasyon konumlandırma ile destinasyonlar rakiplerinden farklılaşarak tercih edilirliklerini artırmaktadırlar. Bu yüzden destinasyonun marka gücünü artırmak doğru konumlama ile mümkündür. Ancak burada konumlandırma yaparken destinasyonun sunabileceklerini göz önünde bulundurarak en optimal faydayı sağlayacak stratejiyi belirlemek gerekir (Castañeda-García vd., 2019). Başarılı bir konumlandırmanın sağlanması için öncelikle hedef kitle ve potansiyel müşteriler tanımlanmalı, rakipler tespit edilerek güçlü-zayıf yönler ortaya konulmalı, rakiplerin fark edemediği boş alan tespit edilerek farklılaşma sağlanmalıdır. Son olarak da marka konumlandırma ifadesi ve mesajı geliştirilip marka kimliği inşa edilmelidir (Taşpınar ve Karakaş, 2017: 19). Turizm ürünlerinde iki tür konumlandırma kullanılmaktadır (Bennett ve Strydom, 2001: 75):

- Objektif konumlandırma; destinasyondaki ürün ve hizmetlerin ziyaretçilerin talep ve ihtiyaçları doğrultusunda şekillendirilmesidir. Özellikle deneyim sonrası iyileştirmelerin yapılması ve duyurulması sağlanabilir.

- Sübjektif konumlandırma; turiste sunulan ürünlerden bağımsız olarak potansiyel turistlerin destinasyon hakkında sahip oldukları imaja şekil verme ve güçlendirme faaliyetleridir.

Kotler (2011) konumlandırma stratejilerini yediye ayırmıştır ve Akpulat (2017) bu stratejilerin destinasyonların marka konumlandırma faaliyetlerinde de kullanılmasının mümkün olduğunu ifade etmiştir. Kotler'in yedi konumlandırma stratejisi şu şekilde sıralanmaktadır (Akpulat, 2017: 5-6); 
- Vasıf konumlandırması: Ürünün sahip olduğu niteliğe, özelliğe göre konumlandırılmasıdır. Bir otelin kendini kentin en yüksek oteli olarak konumlandırması, bir işletmenin kendini bölgenin en eski işletmesi olarak konumlandırması örnek olarak verilebilmektedir.

- Yarar konumlandırması: Burada ürün, tüketiciler için bir fayda vaat etmektedir. Pazarlamacılar çoğunlukla markanın sağladığı fonksiyonel faydalara odaklanırlar. Örneğin; Volvo müşterilerine güvenlik vaat ederken, bir termal otel müşterilerine sağllk, şifa vaat edebilmektedir.

- Kullanım/uygulama konumlandırması: Ürünün kullanım amacına vurgu yapılarak gerçekleştirilen konumlandırmadır. Burada ürünün özellikle nerede nasıl hangi amaçla kullanılacağının altı çizilir. Nike'ın ayakkabılarının bir kısmını koşu için tanıtırken, bir kısmını basketbol, bir kısmını da yürüyüş için en uygun olarak tanitması örnek verilebilmektedir.

- Kullanıcı konumlandırması: Hedef pazar odak noktası alınarak konumlandırılmaktadır. Fanta markası enerjik, kendini rahat hisseden kişilere, Lewis markası kendini bağımsız hisseden kişilere hitap etmektedir.

- Rakip konumlandırması: Ürünün, rakibin ürünlerinden farklılığına vurgu yapılarak yapılan konumlandırmadır. Büyük arabaların çok tercih edildiği dönemde Volkswagen "think small" sloganıyla fark yaratmıştır.

- Kategori konumlandırmast: İşletmenin benzer ürünleri üreten rakipleri ile kendini aynı kategoride düşünüp onların lideri olduğunu ifade etmesi ve tüketici zihninde bu şekilde konumlanmaya çalıştığ 1 faaliyetelerdir.

- Kalite/fiyat konumlandırmast: Kalite-fiyat veya fiyat-performans olarak dile getirilen maliyete göre en yüksek faydanın sunulduğunun iddia edilmesidir. BİM, düşük maliyet düşük kalite olarak konumlandırılırken; BMW, yüksek kalite yüksek fiyat olarak konumlandırılmıştır.

\section{Yöntem}

$\mathrm{Bu}$ çalışmanın amacı, Türkiye'de öne çıkan bazı turistik destinasyonların web sayfalarındaki konumlandırma stratejilerinin belirlenmesidir. Sosyal gezi sayfalarında hakkında paylaşım yapılan yedi destinasyon belirlenmiştir. Bunlar; Çıldır Gölü, Salda Gölü, Seferihisar, Isparta-Kuyucak Köyü, Göbeklitepe, Bozcaada ve Ormanya-Hobbit Köyü'dür. Bu çekim yerlerinin konu edindiği 10 kurumsal web sayfası ele alınmış ve ilgili sayfalarda bu çekim yerlerine yönelik başlıklar içerisinde yer alan temel özellikler içerik analizi yöntemi ile değerlendirilmiştir. Bu yöntemde "yapılan temel işlem belirli kavramlar ve temalar çerçevesinde birbirine benzer verileri bir araya getirerek daha anlaşılır bir şekilde düzenleme yapmak ve yorumlamaktır" (Erdoğan ve Büyüker, 2017: 1084-1085). Web sayfalarındaki içerikler 03.03.2020-08.03.2020 tarihleri arasında yazılı dokümana dönüştürülmüş ve araştırmacılar tarafından web sayfalarında turistlere yönelik verilen mesajlardan alt temalar oluşturulmuştur. Araştırmada kullanılan ana temalar ise Kotler'in (2011) ifade ettiği yedi konumlandırma stratejisidir. Verilmek istenen mesajlar Kotler'in konumlandırma stratejilerine göre ele alınmıştır.

\section{Bulgular}

Çalışmada 10 tane kurumsal web sayfası içerik analizine tabi tutulmuştur. Web sitelerinden hareketle destinasyonların konumlandırabileceği 31 farklı tema belirlenmiştir. Bu temalar; "Koruma Altında, Değerli, Kültürel Zenginlik, Doğal Güzellik, Trend, Çeşitlilik, Coğrafi Konum, Misafirperver, Tarih, Büyüklük, Eşsizlik, Üstünlük, Fayda, Markalaşma, Örnek, İklim, Sürdürülebilir, Keşifsel, Rakip, Çekici, Büyüleyici, En Eski, Sıra dışı, Sanatsal, Gizemli, Özgün, Gastronomi, Turist Profili, Masalsı, Ekoloji, Ulaşılabilirlik"tir. Belirlenen bu temalardan yola çıkarak destinasyonların kullandığı konumlandırma stratejileri tablolarda gösterilmiştir.

Tablo 2'de Çıldır Gölü'ne ait oluşturulan alt temalar ve bu temaların konumlandırma stratejileriyle eşleştirilmesi yer almaktadır. Çıldır Gölü; “Koruma Altında, Değerli, Kültürel Zenginlik, Doğal Güzellik, Trend, Çeşitlilik, Coğrafi Konum, Misafirperver, Tarih" temalariyla destinasyonun özelliklerine vurgu yaptığı için özellik konumlandırması, "Büyüklük" temasıyla rakiplerine göre kıyaslama yaptığı için rakip 
konumlandırması, “Eşsizlik” temasıyla da bulunduğu kategoride tek olduğu vurgusunu yaparak kategori konumlandırması yapmıştır.

Tablo 2. Web Sayfalarında Yer Alan İfadeler, Temalar ve Konumlandırma Stratejileri

\begin{tabular}{|c|c|c|c|}
\hline DESTİNASYON & WEB SİTEDE YER ALAN IFADELER & ALT TEMA & $\begin{array}{l}\text { UYGULANAN } \\
\text { KONUMLANDIRMA } \\
\text { STRATEJISİ }\end{array}$ \\
\hline \multirow{11}{*}{$\begin{array}{l}\text { Çıldır Gölü } \\
\text { Kars } \\
\text { Ardahan }\end{array}$} & $\begin{array}{l}\text { Cumhurbaşkanlığınca "hassas alan" olarak } \\
\text { koruma altına alınmıştır. }\end{array}$ & Koruma Altında & \multirow{9}{*}{ Özellik Konumlandırması } \\
\hline & İlin ve bölgenin önemli bir değeridir. & Değerli & \\
\hline & $\begin{array}{l}\text { Sayısız maddi ve manevi kültürel öğeyi bir araya } \\
\text { getirmiştir. }\end{array}$ & $\begin{array}{l}\text { Kültürel } \\
\text { Zenginlik }\end{array}$ & \\
\hline & Doğal güzellikleriyle çok zengindir. & Doğal Güzellik & \\
\hline & $\begin{array}{l}\text { Son zamanlarda turistlerin en çok tercih ettiği } \\
\text { destinasyondur. }\end{array}$ & Trend & \\
\hline & $\begin{array}{l}\text { Çeşitli turizm aktivitelerine ev sahipliği } \\
\text { yapmaktadır. }\end{array}$ & Çeşitlilik & \\
\hline & $\begin{array}{l}\text { Doğu Ekspresi ile birlikte bölgeye ciddi bir turizm } \\
\text { akını başlayarak, bu bölgeye gelen bütün } \\
\text { turistlerin de mutlak suretle uğradıkları yerdir. }\end{array}$ & Coğrafi Konum & \\
\hline & $\begin{array}{l}\text { "Uluslararası Kristal Göl Kış Şöleni" festivaline ev } \\
\text { sahipliği yaparak binlerce turist ağırlamaktadır. }\end{array}$ & Misafirperver & \\
\hline & $\begin{array}{l}\text { Yıllardır pek çok medeniyete ev sahipliği } \\
\text { yapmıştır. }\end{array}$ & Tarih & \\
\hline & Bölgenin 2. büyük gölüdür. & Büyüklük & Rakip Konumlandırması \\
\hline & Türkiye'nin en derin olup donan tek gölüdür. & Eşsizlik & Kategori Konumlandırması \\
\hline
\end{tabular}

Tablo 3'te Salda Gölü'ne ait oluşturulan alt temalar ve bu temaların konumlandırma stratejileriyle eşleştirilmesi yer almaktadır. Salda Gölü; "Eşsizlik" temasıyla bulunduğu kategoride tek olduğu vurgusunu yaparak kategori konumlandırması, "Üstünlük” temasıyla rakiplerine göre kıyaslama yaptı̆̆ı için rakip konumlandırması, "Fayda" temasıyla destinasyonun turistik tüketicilere bir yarar vaat ettiğini ileri sürerek yarar konumlandırması, “Koruma Altında, Trend, Markalaşma, Doğal Güzellik” temalarıyla da destinasyonun özelliklerine vurgu yaptığı için özellik konumlandırması yapmıştır.

Tablo 3. Web Sayfalarında Yer Alan İfadeler, Temalar ve Konumlandırma Stratejileri

\begin{tabular}{|c|c|c|c|}
\hline DESTINASYON & WEB SİTEDE YER ALAN IFADELER & ALT TEMA & $\begin{array}{l}\text { UYGULANAN } \\
\text { KONUMLANDIRMA } \\
\text { STRATEJISII }\end{array}$ \\
\hline \multirow{7}{*}{$\begin{array}{l}\text { Salda Gölü } \\
\text { Burdur }\end{array}$} & $\begin{array}{l}\text { Türkiye' nin en berrak, en temiz ve en derin tatlı } \\
\text { su göllüdür. Eşine ender rastlanacak beyazlıkta } \\
\text { kumsalları vardır. }\end{array}$ & Eşsizlik & Kategori Konumlandırması \\
\hline & $\begin{array}{l}\text { Dünya'da Mars gezegeninin özelliklerini } \\
\text { taşıyan iki yerden biridir. }\end{array}$ & Üstünlük & Rakip Konumlandırması \\
\hline & $\begin{array}{l}\text { Göl kıyılarında bulunan kil, cilt hastalıklarına iyi } \\
\text { gelmektedir. }\end{array}$ & Fayda & Yarar Konumlandırması \\
\hline & Salda Gölü sit alanı ilan edilmiştir. & Koruma Altında & \multirow{4}{*}{ Özellik Konumlandırması } \\
\hline & $\begin{array}{l}2019 \text { yılına damga vuran 'Türkiye'nin Maldivleri' } \\
\text { olarak ünlenen Salda Gölü'nü 2019'da } 1 \text { milyon } \\
400 \text { bin kişinin ziyaret etti. }\end{array}$ & Trend & \\
\hline & $\begin{array}{l}\text { Burdur kimliğinin de üzerinde marka değer } \\
\text { oluşturan bir destinasyondur. }\end{array}$ & Markalaşma & \\
\hline & Bakir güzellikteki ender yerlerdendir. & Doğal Güzellik & \\
\hline
\end{tabular}


Tablo 4'te Seferihisar'a ait oluşturulan alt temalar ve bu temaların konumlandırma stratejileriyle eşleştirilmesi yer almaktadır. Seferihisar; "Eşsizlik" temasıyla bulunduğu kategoride tek olduğu vurgusunu yaparak kategori konumlandırması, “Örnek" temasıyla rakiplerine göre kıyaslama yaptı̆̆ı için rakip konumlandırması, "İklim, Markalaşma, Sürdürülebilir" temalarıyla da destinasyonun özelliklerine vurgu yaptığı için özellik konumlandırması yapmıştır.

Tablo 4. Web Sayfalarında Yer Alan İfadeler, Temalar ve Konumlandırma Stratejileri

\begin{tabular}{|c|c|c|c|}
\hline DESTINASYON & WEB SİTEDE YER ALAN İFADELER & ALT TEMA & $\begin{array}{l}\text { UYGULANAN } \\
\text { KONUMLANDIRMA } \\
\text { STRATEJISII } \\
\end{array}$ \\
\hline \multirow{5}{*}{$\begin{array}{l}\text { Seferihisar } \\
\text { İzmir }\end{array}$} & $\begin{array}{l}\text { Türkiye'nin en çok mavi bayrağına sahip } \\
\text { ilçesidir. }\end{array}$ & Eşsizlik & Kategori Konumlandırması \\
\hline & $\begin{array}{l}\text { İlk "Cittaslow" (Sakin Şehir) kentlerinden biri } \\
\text { olmayı başaran Seferihisar, diğer kentlere de } \\
\text { örnektir. }\end{array}$ & Örnek & Rakip Konumlandırması \\
\hline & Olağanüstü güzel iklime sahiptir. & İklim & \multirow{3}{*}{ Özellik Konumlandırması } \\
\hline & $\begin{array}{l}\text { Seferihisar Cittaslow (Sakin Şehir) Başkenti } \\
\text { olarak markalaşan bir destinasyondur. }\end{array}$ & Markalaşma & \\
\hline & $\begin{array}{l}\text { Çevresel sürdürülebilirlik ilkesini benimseyerek } \\
\text { turizm yapmaktadır. }\end{array}$ & Sürdürülebilir & \\
\hline
\end{tabular}

Tablo 5'te Kuyucak Köyü'ne ait oluşturulan alt temalar ve bu temaların konumlandırma stratejileriyle eşleştirilmesi yer almaktadır. Kuyucak; "Keşifsel, Eşsizlik" temasıyla bulunduğu kategoride tek olduğu vurgusunu yaparak kategori konumlandırması, "Rakip" temasıyla rakiplerine göre kıyaslama yaptığı için rakip konumlandırması, "Çeşitlilik" temasıyla destinasyondaki ürün veya hizmetlerin kullanım/uygulama alanlarının çeşitliliğine vurgu yaptığı için kullanım/uygulama konumlandırması, “Trend, Çekici, Büyüleyici, Markalaşma” temalarıyla da destinasyonun özelliklerine vurgu yaptığı için özellik konumlandırması yapmıştır.

Tablo 5. Web Sayfalarında Yer Alan İfadeler, Temalar ve Konumlandırma Stratejileri

\begin{tabular}{|c|c|c|c|}
\hline DESTINASYON & WEB SİTEDE YER ALAN İFADELER & ALT TEMA & $\begin{array}{l}\text { UYGULANAN } \\
\text { KONUMLANDIRMA } \\
\text { STRATEJISİ }\end{array}$ \\
\hline \multirow{8}{*}{$\begin{array}{l}\text { Kuyucak Köyü } \\
\text { Isparta }\end{array}$} & $\begin{array}{l}\text { Türkiye' de keşfedilmeyi bekleyen gizli kalmış en } \\
\text { önemli } 9 \text { yerden birincisi konumundadır. }\end{array}$ & Keşifsel & \multirow[t]{2}{*}{ Kategori Konumlandırmas } \\
\hline & $\begin{array}{l}\text { Türkiye'de lavanta üretiminde lokomotif üretici } \\
\text { konumundadır. }\end{array}$ & Eşsizlik & \\
\hline & $\begin{array}{l}\text { Fransa'nın Provence bölgesini anımsatan Kuyucak } \\
\text { lavanta tarlaları Fransa'ya rakip olabilecek } \\
\text { potansiyeldedir. }\end{array}$ & Rakip & Rakip Konumlandırması \\
\hline & $\begin{array}{l}\text { İlaç sanayinden kozmetiğe, gıdadan parfümeri } \\
\text { sektörüne kadar pek çok kullanım alanında üretici } \\
\text { konumundadır. }\end{array}$ & Çeşitlilik & $\begin{array}{l}\text { Kullanım Uygulama } \\
\text { Konumlandırması }\end{array}$ \\
\hline & $\begin{array}{l}\text { Her yıl milyonlarca ziyaretçinin akın ettiği bir } \\
\text { destinasyondur. }\end{array}$ & Trend & \multirow{4}{*}{ Özellik Konumlandırması } \\
\hline & $\begin{array}{l}\text { Bu köy lavantalarıyla dikkat çektiği için "Lavanta } \\
\text { Kokulu Köy" olarak biliniyor. }\end{array}$ & Çekici & \\
\hline & $\begin{array}{l}\text { Sokakları, kerpiç evleri ve kaldırım kenarlarından } \\
\text { adeta fışkırırcasına yetişmiş lavanta öbekleri } \\
\text { görenleri kendisinden geçirmektedir. }\end{array}$ & Büyüleyici & \\
\hline & Lavanta üreticisi olarak markalaşma yolundadır. & Markalaşma & \\
\hline
\end{tabular}


Tablo 6'da Göbeklitepe için oluşturulan alt temalar ve bu temaların konumlandırma stratejileriyle eşleştirilmesi yer almaktadır. Göbeklitepe; “En Eski” temasıyla rakiplerine göre kıyaslama yaptığı için rakip konumlandırması, "Eşsizlik" temasıyla bulunduğu kategoride tek olduğu vurgusunu yaparak kategori konumlandırması, "Sıra dışı, Sanatsal, Koruma Altında, Gizemli" temalarıyla da destinasyonun özelliklerine vurgu yaptığı için özellik konumlandırması yapmıştır.

Tablo 6. Web Sayfalarında Yer Alan İfadeler, Temalar ve Konumlandırma Stratejileri

\begin{tabular}{|c|c|c|c|}
\hline DESTINASYON & WEB SİTEDE YER ALAN İFADELER & ALT TEMA & $\begin{array}{l}\text { UYGULANAN } \\
\text { KONUMLANDIRMA } \\
\text { STRATEJISI }\end{array}$ \\
\hline \multirow{6}{*}{$\begin{array}{l}\text { Göbeklitepe } \\
\text { Şanlıurfa }\end{array}$} & Misır piramitlerinden 7.500 yıl daha eskidir. & En Eski & Rakip Konumlandırması \\
\hline & $\begin{array}{l}\text { Dünyanın bilinen ilk ve en büyük tapınma (kült) } \\
\text { merkezidir. }\end{array}$ & Eşsizlik & Kategori Konumlandırması \\
\hline & $\begin{array}{l}\text { Sıra dışı bulguları Neolitik Çağ'la ilgili pek çok } \\
\text { bilgiyi altüst etmiştir. }\end{array}$ & Sıra dişı & \multirow{4}{*}{ Özellik Konumlandırması } \\
\hline & $\begin{array}{l}\text { Göbeklitepe kazılarından çıan görkemli sanat } \\
\text { eserleri ve heykelcikler vardır. }\end{array}$ & Sanatsal & \\
\hline & $\begin{array}{l}2018 \text { yılında UNESCO Dünya Mirası Listesi'ne } \\
\text { girerek, Türkiye'de } 2019 \text { "Göbeklitepe Yılı" ilan } \\
\text { edilmiştir. }\end{array}$ & $\begin{array}{l}\text { Koruma } \\
\text { Altında }\end{array}$ & \\
\hline & $\begin{array}{l}\text { Kazılarda ortaya çıkan bulgular, buraya ilgiyi her } \\
\text { geçen gün daha çok arttırmaktadır. }\end{array}$ & Gizemli & \\
\hline
\end{tabular}

Tablo 7'de Bozcaada için oluşturulan alt temalar ve bu temaların konumlandırma stratejileriyle eşleştirilmesi yer almaktadır. Bozcaada; "Eşsizlik" temasıyla bulunduğu kategoride tek olduğu vurgusunu yaparak kategori konumlandırması, "Büyüklük” temasıyla rakiplerine göre kıyaslama yaptığı için rakip konumlandırması, "Koruma Altında, Özgün, Çekici, Doğal Güzellik, Gastronomi, Trend, Sürdürebilir" temalarıyla da destinasyonun özelliklerine vurgu yaptığı için özellik konumlandırması yapmıştır.

Tablo 7. Web Sayfalarında Yer Alan İfadeler, Temalar ve Konumlandırma Stratejileri

\begin{tabular}{|c|c|c|c|}
\hline DESTINASYON & WEB SITEDE YER ALAN İFADELER & ALT TEMA & $\begin{array}{l}\text { UYGULANAN } \\
\text { KONUMLANDIRMA } \\
\text { STRATEJISİ }\end{array}$ \\
\hline \multirow{9}{*}{ Bozcaada Çanakkale } & Türkiye' de köyü olmayan tek ilçesidir. & Eşsizlik & Kategori Konumlandırması \\
\hline & Türkiye'nin 3. Büyük adasıdır. & Büyüklük & Rakip Konumlandırması \\
\hline & $\begin{array}{l}\text { Adanın tamamının doğal ve arkeolojik sit alanı ilan } \\
\text { edilmiştir. }\end{array}$ & Koruma Altında & \multirow{7}{*}{ Özellik Konumlandırması } \\
\hline & $\begin{array}{l}\text { Eski mimari dokusu korunarak, kendine özgü yapı } \\
\text { tarzı dikkate alınarak yapılmaktadır. }\end{array}$ & Özgün & \\
\hline & $\begin{array}{l}\text { Temiz, geniş, uzun plajı ve oldukça serin suyu } \\
\text { Bozcaada'nın kıyılarını çekici hale getirmektedir. }\end{array}$ & Çekici & \\
\hline & $\begin{array}{l}\text { Uzun kumsalı ve masmavi denizi oldukça } \\
\text { etkileyicidir. }\end{array}$ & Doğal Güzellik & \\
\hline & $\begin{array}{l}\text { Bozcaada'nın ünü sınırlarını aşan değerlerinin } \\
\text { başında Çavuş Üzümü, bağları, bağ evleri, şarapları, } \\
\text { deniz ürünleri ve zeytinyağlıları gelmektedir. }\end{array}$ & Gastronomi & \\
\hline & $\begin{array}{l}\text { Son yillarda turizm konusunda gözde bir ada haline } \\
\text { gelmiştir. }\end{array}$ & Trend & \\
\hline & $\begin{array}{l}\text { Ekoturizm anlayışı ve sürdürülebilirlik ile ön plana } \\
\text { çıkmıştır. }\end{array}$ & Sürdürebilir & \\
\hline
\end{tabular}

Tablo 8'de Ormanya için oluşturulan alt temalar ve bu temaların konumlandırma stratejileriyle eşleştirilmesi yer almaktadır. Ormanya; "Doğal Güzellik, Trend" temasıyla rakiplerine göre kıyaslama yaptığı için rakip konumlandırması, "Turist Profili” temasıyla destinasyon hedef kullanıcı grubuna hitap ettiği için kullanıcı konumlandırması, "Eşsizlik” temasıyla bulunduğu kategoride tek olduğu vurgusunu yaparak kategori konumlandırması, "Çeşitlilik" temasıyla destinasyondaki ürün veya hizmetlerin 
kullanım/uygulama alanlarının çeşitliliğine vurgu yaptığı için kullanım/uygulama konumlandırması, “Masalsı, Ekoloji, Özgün, Ulaşılabilirlik, Misafirperver" temalarıyla da destinasyonun özelliklerine vurgu yaptığı için özellik konumlandırması yapmıştır.

Tablo 8. Web Sayfalarında Yer Alan İfadeler, Temalar ve Konumlandırma Stratejileri

\begin{tabular}{|c|c|c|c|}
\hline DESTINASYON & WEB SİTEDE YER ALAN İFADELER & ALT TEMA & $\begin{array}{l}\text { UYGULANAN } \\
\text { KONUMLANDIRMA } \\
\text { STRATEJISII } \\
\end{array}$ \\
\hline \multirow{10}{*}{$\begin{array}{l}\text { Ormanya } \\
\text { Kocaeli }\end{array}$} & $\begin{array}{l}\text { Türkiye'nin en önemli doğa turizm destinasyonu } \\
\text { olma potansiyeline sahiptir. }\end{array}$ & Doğal güzellik & \multirow[t]{2}{*}{ Rakip Konumlandırması } \\
\hline & $\begin{array}{l}\text { Milli parklar içinde } 2019 \text { yılında en çok ziyaret } \\
\text { edilen yer olmuştur. }\end{array}$ & Trend & \\
\hline & $\begin{array}{l}\text { Her yaşa hitap eden atölyeler, kurslar ve etkinlikler } \\
\text { bulunmaktadır. }\end{array}$ & Turist Profili & Kullanıcı Konumlandırması \\
\hline & $\begin{array}{l}\text { Avrupa'nın en büyük doğal yaşam alanı olma } \\
\text { özelliğine sahiptir. }\end{array}$ & Eşsizlik & $\begin{array}{c}\text { Kategori } \\
\text { Konumlandırması }\end{array}$ \\
\hline & $\begin{array}{l}\text { İçinde bulunan rekreasyonel faaliyet alanları, } \\
\text { çeşitli turizm türleri, } 6 \text { farklı bölge imkânı ile } \\
\text { kullanım alanları zenginleştirilmiştir. }\end{array}$ & Çeşitlilik & $\begin{array}{l}\text { Kullanım } \\
\text { Uygulama Konumlandırması }\end{array}$ \\
\hline & $\begin{array}{l}\text { Yılın gözdesi küçük evleriyle ziyaretçileri masalsı } \\
\text { bir dünyaya götüren “Ormanköy” olmuştur. }\end{array}$ & Masalsı & \multirow{5}{*}{ Özellik Konumlandırması } \\
\hline & $\begin{array}{l}\text { Doğası ve zengin canlı popülasyonuyla dikkat } \\
\text { çekmektedir. }\end{array}$ & Ekoloji & \\
\hline & $\begin{array}{l}\text { Doğal yaşamın korunması ve turistik amaçlı } \\
\text { kullanımın bir araya getirildiği özgün bir model } \\
\text { ortaya koymaktadır. }\end{array}$ & Özgün & \\
\hline & Kolay ulaşılabilir bir noktada yer almaktadır. & Ulaşılabilirlik & \\
\hline & $\begin{array}{l}\text { “Gamonya; Hayaller Ülkesi” filmine ev sahipliği } \\
\text { yapmıştır. }\end{array}$ & Misafirperver & \\
\hline
\end{tabular}

Tablo 9' da incelemeye alınan destinasyonların web sayfalarında yer alan alt temaların kullanım sıklığ yer almaktadır. Tablo 9'da görüldüğü gibi, genel olarak yükselişteki destinasyonların kullandıkları destinasyon konumlandırmaları incelendiğinde, "Eşsizlik" ve "Trend" temalarının daha çok kullanıldığ 1 görülmektedir. Yapılan analizler sonucunda en az kullanılan temalar ise "Değerli, Kültürel Zenginlik, Coğrafi Konum, Tarih, Üstünlük, Fayda, Örnek, İklim, Keşifsel, Rakip, Büyüleyici, En eski, Sıra dışı, Sanatsal, Gizemli, Özgün, Gastronomi, Ekoloji, Turist Profili, Masalsı, Ulaşılabilir" temalarıdır.

Tablo 9. Destinasyon Konumlandırma Temalarının Kullanma Durumları

\begin{tabular}{|l|l|l|l|}
\hline Tema & Kullanım Durumu & Tema & Kullanım Durumu \\
\hline Koruma Altında & 4 & Sürdürülebilirlik & 2 \\
\hline Değerli & 1 & Keşifsel & 1 \\
\hline Kültürel Zenginlik & 1 & Rakip & 1 \\
\hline Doğal Güzellik & 4 & Çekici & 2 \\
\hline Trend & 5 & Büyüleyici & 1 \\
\hline Çeşitlilik & 3 & En eski & 1 \\
\hline Coğrafi Konum & 1 & Sira dişı & 1 \\
\hline Misafirperver & 2 & Sanatsal & 1 \\
\hline Tarih & 1 & Gizemli & 1 \\
\hline Büyüklük & 2 & Özgün & 2 \\
\hline Esssizlik & 7 & Gastronomi & 1 \\
\hline Üstünlük & 1 & Ekoloji & 1 \\
\hline Fayda & 1 & Turist Profili & 1 \\
\hline Markalaşma & 3 & Masalsı & 1 \\
\hline Örnek & 1 & Ulaşlabilir & 1 \\
\hline İklim & 1 & & \\
\hline
\end{tabular}




\section{Sonuç ve Öneriler}

$\mathrm{Bu}$ çalışmada yükselişte sayılabilecek destinasyonların konumlandırma stratejilerinin içerik analiziyle ortaya koyulması hedeflenmiştir. Çalışma sonucunda bu destinasyonların konumlandırılmasında kullanılan altı strateji belirlenmiştir. Bunlar; Rakip Konumlandırması, Kullanıcı Konumlandırması, Kategori Konumlandırması, Kullanım/Uygulama Konumlandırması, Özellik Konumlandırması ve Yarar Konumlandırmasıdır. Web sitelerdeki ifadelerin temalaştırılması ile oluşturulan bu stratejiler, literatürdeki çalışmalarda geçen stratejilerle benzerlik göstermektedir. Kotler'in (2011) ifade ettiği konumlandırma stratejilerinden altısının incelenen web sayfalarının kullanılmaya çalışıldığı görülmüştür. Nitekim Akpulat (2017) Kotler'in ifade ettiği konumlandırma stratejilerinin destinasyonlar için de kullanılabileceğini ifade etmiştir.

Bulgulara göre, web sayfalarındaki içeriklerden hareketle destinasyonlar için 31 farklı tema belirlenmiştir. Bu temalar; Koruma Altında, Değerli, Kültürel Zenginlik, Doğal Güzellik, Trend, Çeşitlilik, Coğrafi Konum, Misafirperver, Tarih, Büyüklük, Eşsizlik, Üstünlük, Fayda, Markalaşma, Örnek, İklim, Sürdürülebilir, Keşifsel, Rakip, Çekici, Büyüleyici, En Eski, Sıra dışı, Sanatsal, Gizemli, Özgün, Gastronomi, Turist Profili, Masalsı, Ekoloji, Ulaşılabilirlik'tir. Bu temalar, Morçin ve Büyüker (2017) tarafından yapılan çalışmada belirtilen temalarla benzerlik göstermektedir. Oluşturulan temalardan yola çıkarak destinasyonların kullandığ1 konumlandırma stratejileri belirlenmiştir. Yapılan analizler neticesinde Türkiye'de son zamanlarda popülerliği gitgide artan destinasyonların en çok kullandığı konumlandırma temalarının “Eşsizlik, Trend, Doğal Güzellik, Koruma Altında, Çeşitlilik ve Markalaşma" olduğu ortaya çıkmıştır. Buna bağlı olarak da en çok kullanılan stratejiler Özellik Konumlandırması, Rakip Konumlandırması ve Kategori Konumlandırmasıdır. Şıker ve Akın (2012) çalışmalarında konumlandırmada üç temel yaklaşım bulunduğunu, bunların ilk olma, tek olma ve duygulara hitap edebilmek olduğunu ifade etmişlerdir. Bu çalışmada da, destinasyonların birçoğunun öne çıkarmak istediği özelliğe göre ve içinde bulunduğu kategoride ilk/tek olma durumundan kaynaklanan konumlandırmalar ortaya çıkmıştır. Aynı zamanda konumlandırmalarında rakiplerine göre kıyaslama yaparak en büyük, en derin, en çok, tek, ilk destinasyon vb. vurgulayıcı kelimeler ile akılda kalıcılık yaratmaya çalışmışlardır.

Gökaliler (2017), konumlandırmayla ilgili olarak tüketicilere iletilen basit mesajların da konumlandırma başarısını etkilediğini ve tek bir kelimenin bile tüketici zihnini etkileyerek marka ile bağ kurmada önemli olduğunu vurgulamıştır. Bu bağlamda yapılan araştırma çerçevesinde ele alınan destinasyonların konumlandırmasında web sayfaları incelendiğinde birbirine benzerlik gösterdiği ve basit mesajlar kullanılarak destinasyonların az kelimelerle tüketici zihninde yer edindiği ortaya konulmuştur.

Ayrıca incelenen destinasyonların kişilerin duygularına hitap ederek konumlandırma yapmadığı, buna ek olarak pek çok destinasyonun birbirine çok yakın konumlandırma sözcükleri kullandığ1 görülmüştür. Dolayısıyla destinasyonların kaynaklarına ve üstün yönlerine göre ilgi ve merak uyandıracak sözcükleri kullanmaları, yani eşsiz yönleriyle birlikte kişilerin daha çok duygularına hitap edeceği bir konumlandırma ile rakiplerinden farklılaşarak popülerliklerinin ve destinasyona olan talebin artması sağlanabilir. Bu doğrultuda, mevcut destinasyonların yeniden konumlandırmaya giderek, kendilerini rakiplerinden farklılaştıracak konumlandırma stratejileri geliştirmeleri tavsiye edilmektedir. Ayrıca konumlandırma sürecinde, destinasyonların, rakip destinasyonlara göre güçlü ve zayıf yönlerini belirleyerek uygulayacağı politika ve konumlandırma stratejilerini sahip olduğu üstün yönlerine göre temellendirilmesi önemlidir.

Bu çalışma kapsamında ele alınan destinasyonlar, kıyı turizmindeki popüler destinasyonlardan ziyade alternatif turizm destinasyonları gibi düşünülebilir. İncelenen destinasyonların kendilerine has farklı özellikleri olduğu için birbirleri ile kıyaslama yapılmamıştır. Bu çalışmada destinasyonlara ait kurumsal web sayfalarında yer alan açılamalar üzerinden değerlendirmeler yapılmıştır. Kurumsal web sayfalarının etkinliği ölçülmemiştir. En önemli konulardan bir tanesi bu sitelerin turisti harekete geçirecek ve destinasyona yönelik farkındalığı ve farklılığı arttıracak içeriklerle zenginleştirilmesinin yanında turistler tarafından da takip edilmesidir. Bu çalışmada yalnızca adı geçen yükselişteki destinasyonların 
kurumsal web sayfalarında kendilerini nasıl konumlandırmaya çalıştıkları tespit edilmeye çalışılmıştır. Ancak bu web sitelerinin bu çekim yerlerini ziyaret eden veya etmeyi düşünen turistler üzerindeki etkisi ve verimliliğinin araştırılması önemli bir konudur. Bu destinasyonların turistlerin zihninde nasıl konumlandığı ve bu konumlandırmada etkili olan mesajların neler olduğu ve turiste nasıl ulaştığı da önemli konulardır. Gelecekte bahsedilen bu konularla ilgili yapılacak çalışmalar destinasyonların konumlandırılmasını yönetmeyi kolaylaştırabilir.

\section{Kaynaklar}

Akpulat, Nükhet A. (2017). Turistik destinasyonlarda pazarlama kararlarının marka konumlandırma açısından değerlendirilmesi; Çeşme ilçesine yönelik bir alan araştırması. Ege Üniversitesi İşletme Araştırmaları Dergisi, 9 (3), 444-448.

Alili, M. (2017). Avrupa'daki ve Türkiye'deki hüzün turizmi destinasyonlarının karşılaştırması üzerine teorik bir çalışma. Uluslararası Global Turizm Araştırmaları Dergisi, 1 (1), 37-50.

Atsız, O. ve İ. Kızılırmak. (2017). Mardin'in doğal ve kültürel çekiciliklerinin destinasyon pazarlaması kapsamında incelenmesi. Mardin Artuklu Üniversitesi Sosyal Bilimler Enstitüsü Dergisi, 8(1), 28-29.

Aydınol, P (2010). Marka konumlandırmada tüketici algılama haritaları: Bir uygulama. Yüksek lisans tezi, Dokuz Eylül Üniversitesi Sosyal Bilimler Enstitüsü, İzmir.

Bennett, J. A. \& Strydom, J. W. (2001). Introduction to travel and tourism marketing. Lansdowne: Creda Communications, p.107.

Bozcaada, http://www.bozcaada.gov.tr , erişim tarihi: 03.03.2020

Castañeda-garcía, J. A., Frías-Jamilena, D. M., Del Barrio-García, S., \& Rodríguez-Molina, M. A. (2020). The effect of message consistency and destination-positioning brand strategy type on consumerbased destination brand equity. Journal Of Travel Research, 59(8), 1447-1463.

Cengiz, B. (2006). Tüketici davranışları açısından stratejik pazar konumlandırması ve Piyale'nin konumlandırma çalışmalarının incelenmesi. Yüksek lisans tezi, Dokuz Eylül Üniversitesi Sosyal Bilimler Enstitüsü, İzmir.

Chernikova, L. I., Faizova, G. R., Egorova, E. N. \& Silaeva, A. A. (2015). Increase of competitiveness of tourist industry companies on the basis of marketing approaches. Mediterranean Journal of Social Sciences, $6(6$ s4), 99.

Çakır, M. (2017). Yeşil ürün grupları çerçevesinde marka ve markalama kararları. Siirt Üniversitesi Sosyal Bilimler Enstitüsü Dergisi, (9), 333-378.

Çatı, K., Ö. Kethüda, Y. Bilgin. (2016). Üniversitelerin konumlandırma stratejileri: İstanbul'daki üniversiteler üzerine bir inceleme. Eğitim ve Bilim, 41 (185), 220.

Çıldır Gölü, http://cildir.gov.tr , erişim tarihi: 03.03.2020

Çıldır Gölü, http:// http://www.ardahan.gov.tr/sehrimiz erişim tarihi: 03.03.2020

Çifci, S., \& Cop, R. (2007). Marka ve marka yönetimi kavramları: üniversite öğrencilerinin kot pantolon marka tercihlerine yönelik bir araştırma. Finans Politik \& Ekonomik Yorumlar, 44(512), 69-88.

Erdoğan, Morçin S. Ve Büyüker, İşler D. (2017). Destinasyon sloganlarında kullanılan temaların analizi. Süleyman Demirel Üniversitesi İktisadi ve İdari Bilimler Fakültesi Dergisi, 22 (4), 1084-1085.

Ersun, N. ve K. Arslan. (2011). Turizmde destinasyon seçimini etkileyen temel unsurlar ve pazarlama stratejileri. Marmara Üniversitesi İ.I.B.F. Dergisi, 31 (2), 229-248.

Evren, S. (2016). Türkiye'de kış turizmi destinasyonlarının rekabetçi konumlandırması. Doktora tezi, Anadolu Üniversitesi, Sosyal Bilimler Enstitüsü, Turizm İşletmeciliği Anabilim Dalı, Eskişehir. 
Türkmen, S., İlban, M. O. \& Karakaş, M. (2021). Türk Turizminde Yükselen Destinasyonların Konumlandırma Stratejilerinin Belirlenmesi. GSI Journals Serie A: Advancements in Tourism, Recreation and Sports Sciences (ATRSS), 4 (2): 37-48.

Fuchs, C., \& Diamantopoulos, A. (2010). Evaluating the effectiveness of brand-positioning strategies from a consumer perspective. European Journal of Marketing, 44 (11/12), 1763 - 1786

Göbeklitepe, http://www.sanliurfa.bel.tr , erişim tarihi: 03.03.2020

Gökaliler, E. (2017). Şehirlerin markalaşması sürecinde marka konumlandırmasının rolü: Seferihisar cittaslow üzerine bir inceleme. Erciyes İletişim Dergisi, 5 (1), 329.

İnce, M. \& Uygurtürk, H. (2019). Marka kimliği, marka kişiliği, marka imajı ve marka konumlandırma alanında yapılan lisansüstü tezlere yönelik bir inceleme. Karabük Üniversitesi Sosyal Bilimler Enstitüsü Dergisi, 9 (1), 224-240.

Jordan, F., \& Gibson, H. (2005). "We're not stupid... But we'll not stay home either": Experiences of solo women travelers. Tourism Review International, 9(2), 195-211.

Kaba, B. ve G. Emekli. (2018). Turizmde yükselen bir eğilim: yalnız seyahat eden kadın gezginler (Türkiye örneği). Ege Coğrafya Dergisi, 27 (2), 111-126.

Kalafatis, S. P., Tsogas, M. H. \& Blankson, C. (2000). Positioning strategies in business markets. Journal of Business \& Industrial Marketing, 15(6), 416-437.

Kotler, P. (2011). Kotler ve pazarlama. İstanbul: Sistem Yayıncilık.

Kuvvetli, M. (2014). Turizmde destinasyon markalaşması: Şanlıurfa üzerine bir uygulama. Yüksek lisans tezi, Niğde Üniversitesi Sosyal Bilimler Enstitüsü, Niğde.

Ormanya-hobbit Köyü, http://www.kocaeli.gov.tr , erişim tarihi: 03.03.2020

Ormanya-hobbit Köyü, http://www.ormanya.com , erişim tarihi: 03.03.2020

Ormanya-hobbit Köyü, http://www.uzuntarla.tabiat.gov.tr , erişim tarihi: 03.03 .2020

Ormanya-hobbit Köyü,http://www.kocaeli.bel.tr, erişim tarihi: 03.03.2020

Osman, H., Brown, L., \& Phung, T. M. T. (2020). The travel motivations and experiences of female vietnamese solo travellers. Tourist Studies, 20(2), 248-267.

Salda Gölü, http://www.saldagolu.com , erişim tarihi: 03.03.2020

Seferihisar, http://www.seferihisar.bel.tr , erişim tarihi: 03.03.2020

Şıker, P. ve M. Akın. (2012). Konaklama işletmelerinde konumlandırmanın tüketici algılamaları üzerinde etkinliğinin incelenmesi. Ni⿱ğde Üniversitesi İ̈BF Dergisi, 5 (1), 55-56.

Taşpınar, O. ve N. Karakaş. (2017). Destinasyon konumlandırma stratejisi kapsamında cittaslow hareketi; Gökçeada örneği. Aksaray Üniversitesi Sosyal Bilimler Enstitüsü Dergisi, 1 (2), 18-35.

Türkmen, S., Lütfi, A. \& Türkmen, E. (2018). Destinasyon kişiliği, memnuniyet ve davranışsal niyetler arasındaki ilişkilerin incelenmesi: Çanakkale örneği. Journal Of Yaşar University, 13(49), 22-32. 